\title{
Additional G-like Chromosome in a Malformed Boy
}

\author{
M. FRACCARO, MAJ HULTÉN, S. D. JAYAKAR, AGNETA LINDSJÖ, \\ J. LINDSTEN, and L. TIEPOLO
} From EURATOM Unit for Human Radiation and Cyto genetics, and Laboratorio di Genetica Biochimica ed Evolu-
zionistica, c/o Istituto di Genetica, University of Pavia, Italy; and Department of Clinical Genetics, Karolinska
Hospital and Medical Centre of the Board for the Mentally Retarded in Stockholm, Stockholm, Sweden.

\section{Case Report}

This boy was born 2 March 1963, to a 26-year-old mother and a 49-year-old father, who are both healthy. One sister born 1964 and one brother born 1965 are both healthy. There is no history of abortion. There was no consanguinity, twin births, malformations, or developmental disorders known among his close relatives. Pregnancy and delivery were uneventful. No viral infections and no exposure to ionizing radiation or drugs were known. The birthweight was $3960 \mathrm{~g}$. The boy's psychomotor development was considerably delayed, he sat at 12 months and walked at 3 years of age. Pneumoencephalography in 1964 revealed cortical atrophy but a normal skull. He has been at an institution for mentally retarded children since 1966 and is still unable to speak, to understand what is said, and to control micturition and defaecation. At the last examination (1968) the rough motor development corresponded to 18 months and the fine motor development to 28-40 weeks of age. He reacted to sound stimuli but a detailed test of hearing could not be made.

Physical examination. At 5 years of age (Fig. 1) his height was $99 \mathrm{~cm}$ (lower $2 \sigma$ limit $=101 \mathrm{~cm}$ ), weight $13.5 \mathrm{~kg}$, and head circumference $49 \mathrm{~cm}$. He had muscular hypotonia and hypertensible joints. He had a tottering gait with bent knees. Normal sex characteristics. His ears were somewhat large and displaced and with underdeveloped helices. Ophthalmological investigation revealed slight ptosis and a convergent alternating stabismus bilaterally but no coloboma, epicanthic folds, or slanting eyes. His palate vault was flat and broad, but the tongue and teeth were normal. Normal heart sounds. $X$-ray investigations showed normal heart and lungs, no vertebral malformation, hypoplastic middle phalanx on the fifth finger, and normal Caffey's index $\left(53.5^{\circ}\right)$. Moderate, diffuse, and intermittent abnormalities of epileptogenic type were found on an electroencephalogram, but he has never had any epileptic seizures. The spinal fluid contained a normal number of cells and normal amount of proteins. Haemoglobin electrophoresis showed $2 \cdot 2 \% \mathrm{HbA}_{2}$ (normal range of variation $1.9-3 \cdot 1 \%$ ), $0.1 \% \mathrm{HbF}$ (normal range of variation $0-1.9 \%$ ), and no abnormal haemo-

\footnotetext{
Received 16 June 1970.
}

globins. There were no reducing substances, glucose, proteins, cystine, phenylpyruvic acid, porphobilinogen, or chondroitin sulphuric acid in the urine. Two-dimensional chromatography of the urine revealed a normal pattern and high voltage electrophoresis normal amounts of amino acids. Blood groups, serum type, and red cell enzymes are given in Table I. No obvious irregularities were found. Professor L. S. Penrose who performed the dermatoglyphic analysis made the following comments. 'The total ridge-count (105) is low for a male (control mean, 145). The absence of $c$ on both hands is unusual and there are no loops on the palms (Fig. 2).

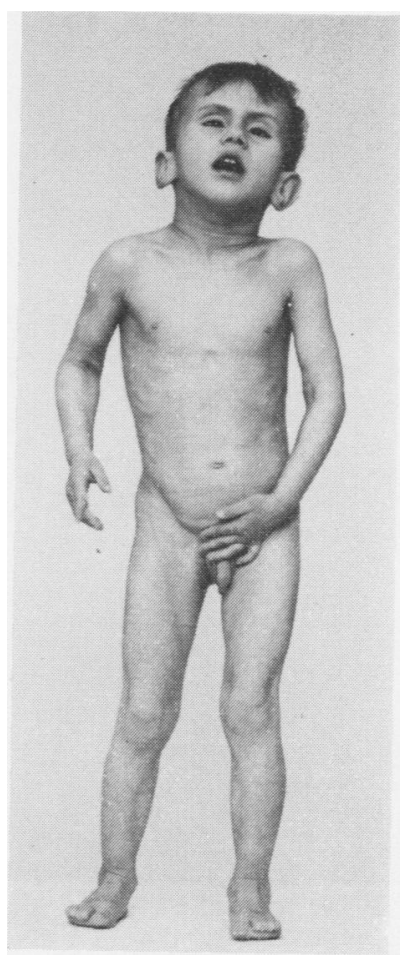

Fig. 1. Patient at 5 years old. 
TABLE I

BLOOD GROUPS, SERUM TYPES, AND RED CELL ENZYMES

\begin{tabular}{|c|c|c|c|c|c|c|c|c|c|c|c|}
\hline & \multirow[b]{2}{*}{ Subject } & \multicolumn{8}{|c|}{ Red Cell Antigens } & & \\
\hline & & A B O & MNSs & $\mathbf{P}_{1}$ & $\mathbf{R h}$ & $\mathbf{K}_{\mathbf{k}}^{\mathrm{K}}$ & $a^{F y}$ & $\mathbf{J k}^{\mathbf{a}}$ & $a^{L c} b$ & & \\
\hline & $\begin{array}{l}\text { Patient } \\
\text { Mother } \\
\text { Father }\end{array}$ & $\begin{array}{l}A_{1} \\
A_{1} \\
A_{1}\end{array}$ & $\begin{array}{l}\text { MNSs } \\
\text { MSMs } \\
\text { MSNS }\end{array}$ & $\begin{array}{l}- \\
+ \\
+\end{array}$ & $\begin{array}{l}\mathbf{R h}_{1} \mathbf{R h}_{2} \\
\mathrm{Rh}_{1} \mathbf{r h} \\
\mathrm{Rh}_{\mathbf{2}} \mathbf{R h _ { 2 }}\end{array}$ & $\begin{array}{ll}- & 2 \\
+ & + \\
- & \end{array}$ & $\begin{array}{l}2 \\
+ \\
+\end{array}$ & $\begin{array}{l}2 \\
+ \\
+\end{array}$ & $\begin{array}{ll}- & 2 \\
- & + \\
- & \end{array}$ & & \\
\hline \multirow{3}{*}{ Subject } & \multicolumn{5}{|c|}{ Serum Types } & \multirow{3}{*}{\multicolumn{2}{|c|}{$\begin{array}{c}\text { Acid } \\
\text { Phosphatases }\end{array}$}} & \multirow{3}{*}{\multicolumn{2}{|c|}{$\begin{array}{l}\text { Phospho- } \\
\text { glucomutase }\end{array}$}} & \multirow{2}{*}{\multicolumn{2}{|c|}{$\begin{array}{l}\text { Pepti- } \\
\text { dase }\end{array}$}} \\
\hline & \multirow{2}{*}{$\begin{array}{l}\text { Hapto- } \\
\text { globin }\end{array}$} & \multirow{2}{*}{$\begin{array}{l}\text { Trans- } \\
\text { ferrin }\end{array}$} & \multirow{2}{*}{$\mathrm{Gm}^{\mathrm{a}}$} & \multirow{2}{*}{ Gc } & \multirow{2}{*}{$\mathbf{A g}^{\mathbf{x}}$} & & & & & & \\
\hline & & & & & & & & & & A 1 & \\
\hline $\begin{array}{l}\text { Patient } \\
\text { Mother } \\
\text { Father }\end{array}$ & $\begin{array}{l}2-1 \\
2-1 \\
2-1\end{array}$ & $\begin{array}{l}\mathrm{C} \\
\mathrm{C}\end{array}$ & $\overline{-}$ & $\begin{array}{l}2-2 \\
2-1 \\
2-1\end{array}$ & $\begin{array}{l}- \\
-\end{array}$ & $\begin{array}{l}\mathbf{B} \\
\mathbf{C} \\
\mathbf{B}\end{array}$ & & & $\begin{array}{c}2-1 \\
2-1 \\
1\end{array}$ & $\begin{array}{l}1 \\
1 \\
1\end{array}$ & $\begin{array}{l}1 \\
1 \\
1\end{array}$ \\
\hline
\end{tabular}
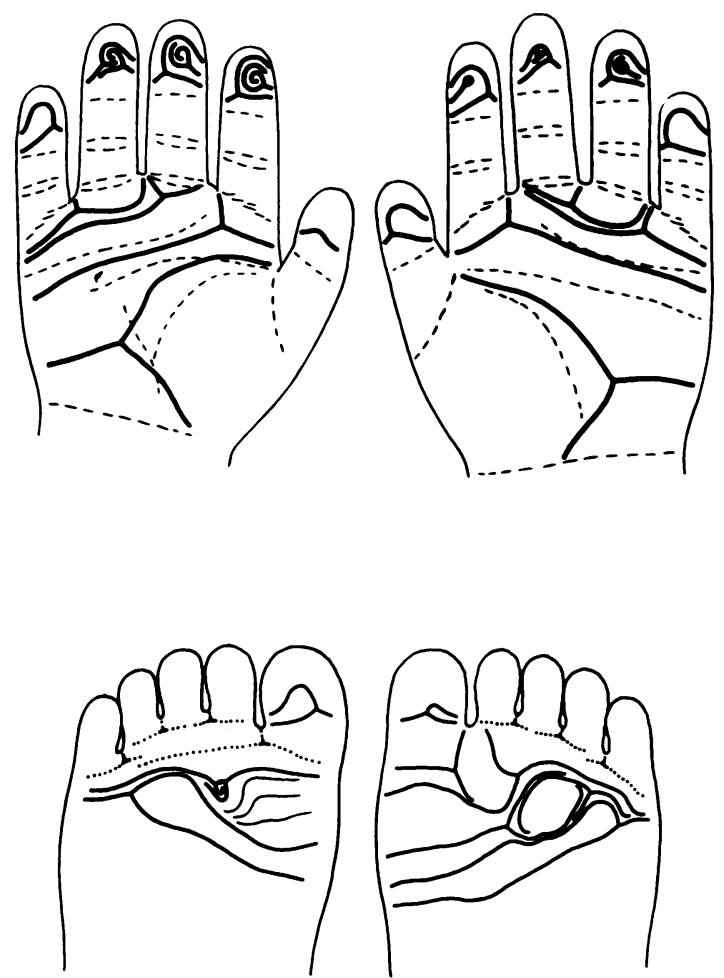

Fig. 2. Dermatoglyphs on the hands and feet of patient (courtesy of Prof. L. S. Penrose).

There is nothing here suggestive of mongolism. The feet of this patient (Fig. 2) are much more interesting than the hands. The system of distal zygodactylous triradii on both soles is unusual; it occurs on about $2 \%$ of normal feet but is very rare in mongolism. The arrangement of these triradii on the left foot is even more unusual and it is associated with a peculiar, very small, whorl on the second interdigital area. In my control data, I have no record of this arrangement nor, indeed, of the four loop configuration on the right sole and I can say with confidence that these sole patterns would never be found in a mongol.'

\section{Chromosome Studies}

The propositus had consistently 47 chromosomes and an extra G-like chromosome. The chromosome counts are given in Table II. In several cells this chromosome appeared to be slightly longer than the other G-chromosomes and to have longer short arms. In other cells, however, it was undistinguishable from the other G chromosomes (Fig. 3). Analysis by fluorescence microscopy after staining with quinacrine dehydrochloride according to Pearson, Bobrow, and Vosa (1970) revealed that the extra chromosome was not a Y chromosome. In all cells analysed there was only one brightly fluorescing G-like chromosome. Controls from an XYY case processed at the same time revealed consistently two fluorescent chromosomes (Fig. 4). Both parents had apparently normal karyotypes.

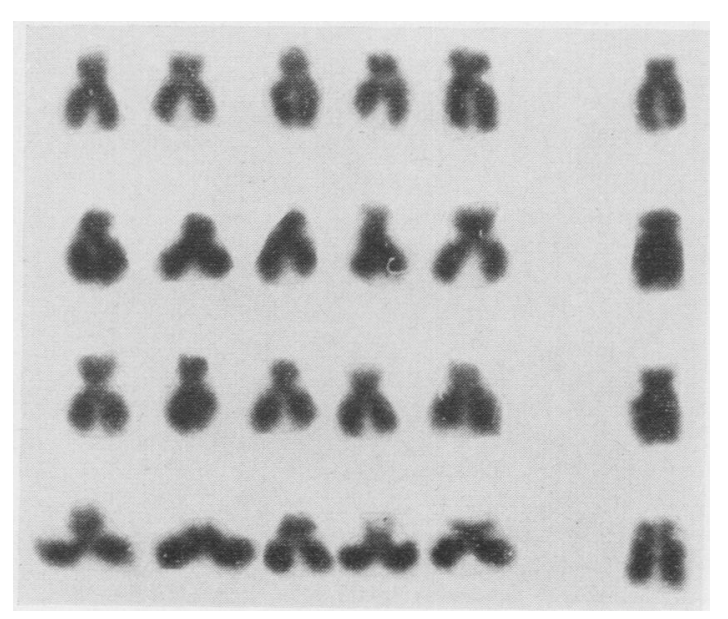

Fig. 3. G group and $Y$ chromosomes from four cells. 
TABLE II

RESULTS OF ANALYSIS OF SEX CHROMATIN IN BUCCAL MUCOSA SMEARS AND OF CHROMOSOME COUNTS

\begin{tabular}{|c|c|c|c|c|c|c|c|c|}
\hline \multirow{2}{*}{ Subject } & \multirow{2}{*}{$\underset{\text { Chromatin }}{\text { Sex }}$} & \multirow{2}{*}{ Culture } & \multicolumn{4}{|c|}{ Number of Chromosomes } & \multirow{2}{*}{$\begin{array}{l}\text { Total No. } \\
\text { of Cells }\end{array}$} & \multirow{2}{*}{ Karyotype } \\
\hline & & & 45 & 46 & 47 & 48 & & \\
\hline $\begin{array}{l}\text { Case } \\
\text { Mother }\end{array}$ & + & $\begin{array}{l}\left\{\begin{array}{l}\text { Blood I } \\
\text { Blood II } \\
\text { Skin }\end{array}\right. \\
\left\{\begin{array}{l}\text { Blood I } \\
\text { Blood II }\end{array}\right.\end{array}$ & $\frac{-}{-}$ & $\begin{array}{l}- \\
\overline{-} \\
98 \\
74\end{array}$ & $\begin{array}{l}25 \\
40 \\
17 \\
2^{*} \\
-\end{array}$ & $\begin{array}{l}- \\
z \\
-\end{array}$ & $\left.\begin{array}{r}25 \\
40 \\
17 \\
100 \\
75\end{array}\right\}$ & $\begin{array}{l}47, X Y, G+ \\
46, X X\end{array}$ \\
\hline Father & - & Blood I & $3+$ & 21 & - & - & 24 & $46, X Y$ \\
\hline
\end{tabular}

* One extra C chromosome in one of these cells, one extra D chromosome in the other.

$+\mathrm{Y}$ or 18 was missing in two cells, an $\mathrm{F}$ chromosome in the third.

Autoradiography was performed on blood cultures labelled with tritiated thymidine for the last 6 hours of culture. Forty-one labelled cells were photographed with and without autoradiographic grains. A qualitative analysis gave inconclusive results. In fact, in 17 cells two of the five $\mathrm{G}$ chromosomes were appreciably more labelled than the other three (Fig. 5), while in the other 14 cells there was precisely the reverse pattern, with three $\mathrm{G}$ chromosomes more labelled than the other two (Fig. 5). Of the remaining cells, five had four G's more labelled and three had one $G$ more labelled than the other four. The $\mathrm{Y}$ chromosome was not much longer than the other chromosomes of the G group, but in most cells it was recognizable for its morphology. In most cells the $\mathrm{Y}$ chromosome was more labelled than the $\mathrm{G}$ chromosomes.

Quantitative analysis. Grain counts were performed on each of the 41 metaphases. The total grain count distribution and the grain count on the individual relevant chromosomes for each cell are shown in Table III. In order to differentiate between the $G$ type chromosomes, a correlation of the grain counts on the $G$ chromosomes with that on the $\mathrm{Y}$ chromosomes was first investigated. It was found useful to plot the grain count on the Gs (what we call $g$ ) against that on the Y chromosome $(y)$. If one assumes that homologous chromosomes are synchronous in their replication, we expect the grain counts on two homologous chromosomes to be equal except for random variation. In this case, where there are five Gs, among the more likely possibilities are the following: (1) That they consist of two normal pairs of Gs and another chromosome which is not homologous to either pair, let us call this the (221) hypothesis. (2) That they consist of a pair of homologous chromosomes and a triplet of the other kind, we will call this the (23) hypothesis. Under the assumption of synchrony and the (221) hypothesis, we expect a pair of counts very
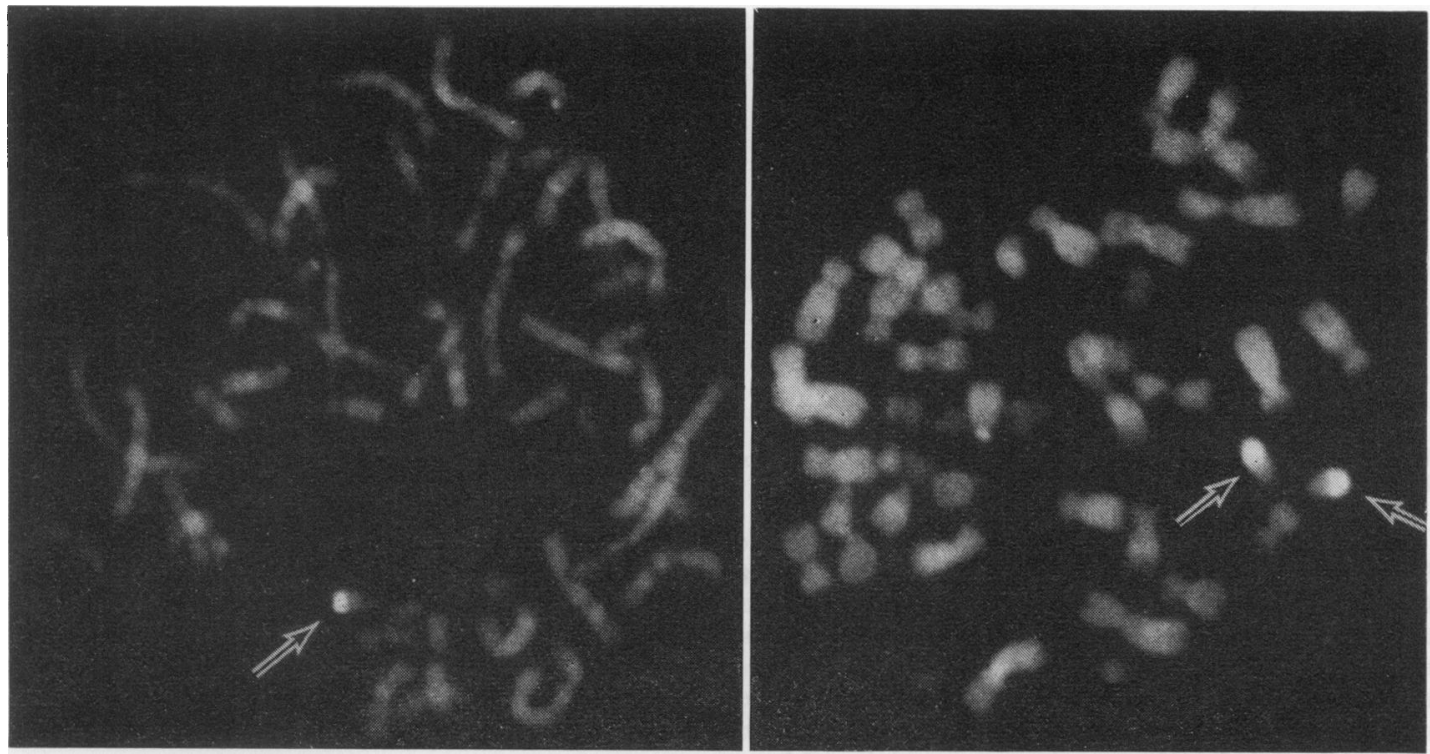

FIG. 4. Left, a mitosis from a blood culture showing one brightly fluorescing $\mathrm{Y}$ chromosome (arrow). Right, a mitosis from an XYY male showing two brightly fluorescing Y chromosomes (arrows). 


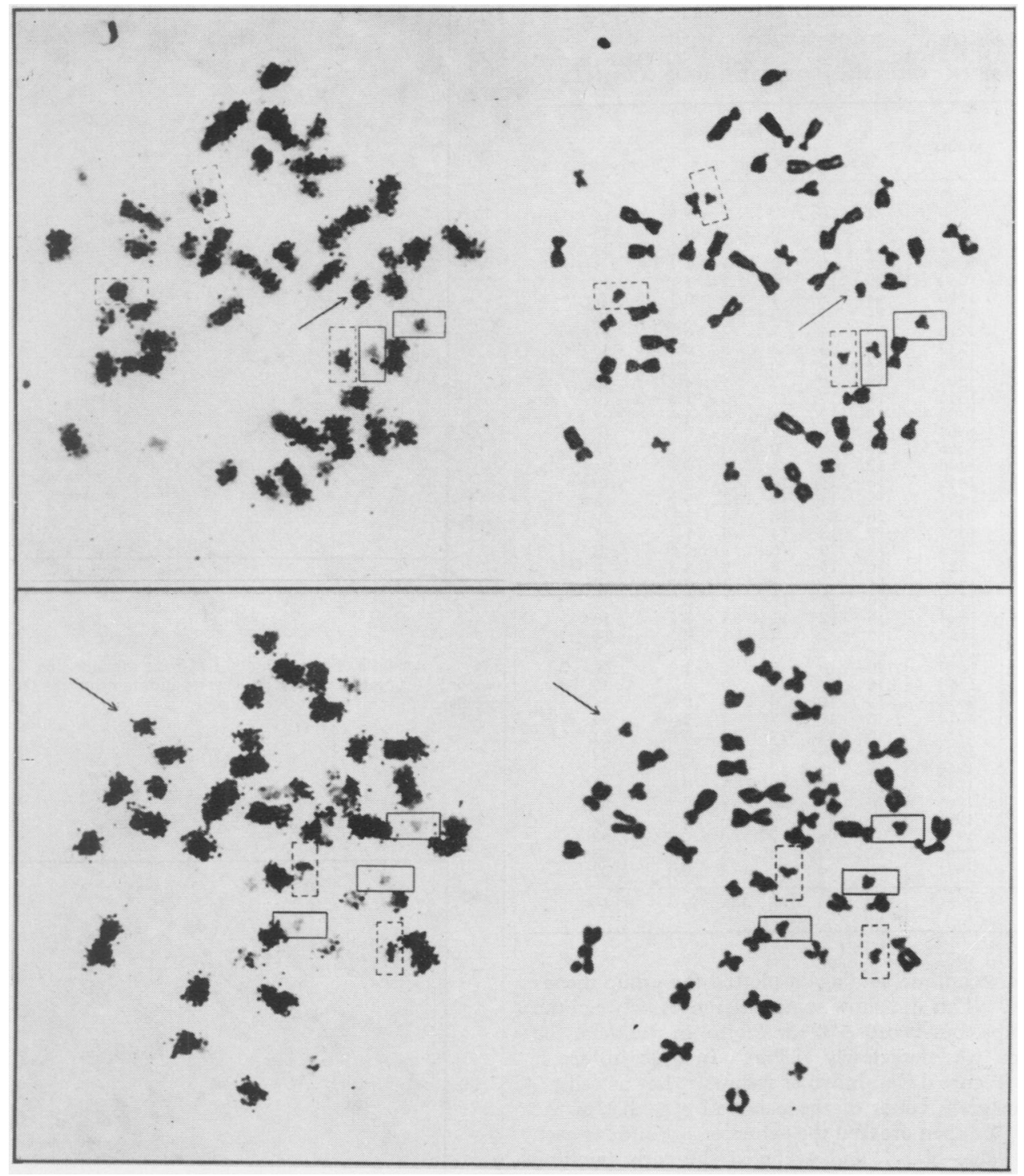

Fig. 5. Labelled metaphases to show the two most common qualitative patterns. At right the same cells without grains. Top, three G chromosomes more labelled (broken boxes) than the other two (box). Bottom, two G chromosomes (broken boxes) more labelled than the other three (boxes). Arrows point to the $Y$ chromosomes.

similar to each other, another such pair independent of the first, and a fifth count independent of either pair. In some cells of course any of these counts may be equal to any other. Under the (23) hypothesis, on the other hand, we expect a pair of similar counts and the other three counts to be very similar to each other, and independent of the pair.

A method of separating the various components of the $\mathrm{G}$ group is to make all possible grouping of the five counts and choose that grouping which minimizes the sum of the within group variances of grain counts. This was done for the data, using an electronic computer. We first considered the (221) hypothesis. The count on the chromosome singled out by minimizing the within group variances $g_{1}$, and the mean count on the other four $g_{2345}$, plotted against $y$ gave no evidence for any differences between the two groups.

We made clusters of two and three chromosomes by 
TABLE III

TOTAL GRAIN COUNTS AND COUNTS OVER G AND Y CHROMOSOMES ARRANGED IN DECREASING ORDER OF TOTAL GRAIN COUNTS

\begin{tabular}{|c|c|c|c|c|c|c|c|}
\hline \multirow{2}{*}{ Cell No. } & \multirow{2}{*}{$\begin{array}{l}\text { Total } \\
\text { grains }\end{array}$} & \multicolumn{6}{|c|}{ Grains on } \\
\hline & & \multicolumn{5}{|c|}{ Five G chromosomes } & Y chromosome \\
\hline $\begin{array}{r}1 \\
2 \\
3 \\
4 \\
5 \\
6 \\
7 \\
8 \\
9 \\
10 \\
11 \\
12 \\
13 \\
14 \\
15 \\
16 \\
17 \\
18 \\
19 \\
20 \\
21 \\
22 \\
23 \\
24 \\
25 \\
26 \\
27 \\
28 \\
29 \\
30 \\
31 \\
32 \\
33 \\
34 \\
35 \\
36 \\
37 \\
38 \\
39 \\
40 \\
41\end{array}$ & $\begin{array}{r}699 \\
886 \\
990 \\
1011 \\
1016 \\
1080 \\
1148 \\
1214 \\
1215 \\
1239 \\
1273 \\
1301 \\
1334 \\
1352 \\
1364 \\
1366 \\
1436 \\
1445 \\
1464 \\
1485 \\
1487 \\
1495 \\
1521 \\
1533 \\
1545 \\
1604 \\
1617 \\
1621 \\
1639 \\
1650 \\
1654 \\
1714 \\
1715 \\
1793 \\
1866 \\
1939 \\
1965 \\
1965 \\
1975 \\
2061 \\
2571\end{array}$ & $\begin{array}{r}5 \\
12 \\
8 \\
10 \\
2 \\
25 \\
16 \\
14 \\
18 \\
18 \\
14 \\
15 \\
18 \\
18 \\
5 \\
10 \\
12 \\
18 \\
15 \\
26 \\
19 \\
13 \\
16 \\
14 \\
20 \\
15 \\
5 \\
4 \\
20 \\
16 \\
13 \\
13 \\
15 \\
16 \\
24 \\
21 \\
23 \\
18 \\
10 \\
26 \\
9\end{array}$ & $\begin{array}{r}3 \\
6 \\
2 \\
7 \\
0 \\
14 \\
8 \\
7 \\
14 \\
16 \\
9 \\
10 \\
17 \\
17 \\
4 \\
9 \\
5 \\
15 \\
14 \\
21 \\
18 \\
9 \\
15 \\
9 \\
17 \\
12 \\
2 \\
4 \\
10 \\
14 \\
10 \\
12 \\
14 \\
6 \\
19 \\
17 \\
19 \\
12 \\
8 \\
22 \\
6\end{array}$ & $\begin{array}{r}0 \\
2 \\
0 \\
1 \\
0 \\
8 \\
4 \\
0 \\
11 \\
8 \\
0 \\
7 \\
11 \\
8 \\
2 \\
0 \\
4 \\
14 \\
14 \\
18 \\
14 \\
6 \\
8 \\
8 \\
12 \\
11 \\
2 \\
1 \\
5 \\
1 \\
6 \\
7 \\
14 \\
4 \\
17 \\
10 \\
16 \\
1 \\
0 \\
6 \\
5\end{array}$ & $\begin{array}{r}0 \\
2 \\
0 \\
0 \\
0 \\
4 \\
0 \\
0 \\
7 \\
0 \\
0 \\
5 \\
6 \\
8 \\
0 \\
0 \\
1 \\
10 \\
12 \\
4 \\
6 \\
4 \\
7 \\
2 \\
1 \\
3 \\
1 \\
0 \\
1 \\
0 \\
5 \\
2 \\
13 \\
3 \\
17 \\
3 \\
9 \\
0 \\
0 \\
5 \\
4\end{array}$ & $\begin{array}{r}0 \\
1 \\
0 \\
0 \\
0 \\
3 \\
0 \\
0 \\
6 \\
0 \\
0 \\
4 \\
1 \\
4 \\
0 \\
0 \\
0 \\
2 \\
3 \\
2 \\
1 \\
2 \\
5 \\
0 \\
0 \\
3 \\
0 \\
0 \\
1 \\
0 \\
0 \\
2 \\
4 \\
0 \\
12 \\
0 \\
2 \\
0 \\
0 \\
0 \\
0\end{array}$ & $\begin{array}{r}10 \\
13 \\
43 \\
26 \\
3 \\
30 \\
27 \\
16 \\
27 \\
30 \\
21 \\
38 \\
19 \\
27 \\
10 \\
16 \\
24 \\
30 \\
18 \\
29 \\
31 \\
42 \\
24 \\
17 \\
23 \\
18 \\
14 \\
5 \\
35 \\
30 \\
37 \\
69 \\
21 \\
37 \\
28 \\
50 \\
24 \\
26 \\
32 \\
28 \\
22\end{array}$ \\
\hline Totals & $61 \cdot 248$ & 609 & 453 & 266 & 145 & 58 & 1.070 \\
\hline
\end{tabular}

the same technique, and again plotted the group means against $y$. This did show some differences between the two groups, but because of the 'noise' in the data, the separation was not clearly visible. In order to see it better. Figure 6 was drawn as follows. Let us call $g_{12}$ the mean grain count of the pair and $g_{345}$ that of the triplet. We then ordered the values of $g_{12}$, and for each distinct value of $g_{12}$, and averaged the corresponding values of $y$ which were then plotted. The same procedure was carried out for $g_{345}$. The separation was seen very clearly. As a control the same was done for $g_{1}$ and $g_{2345}$ against $y$. The result, as seen in Fig. 7 showed no separation. We obtained therefore, from this analysis, evidence that the $\mathrm{G}$ complex might consist of a pair and a triplet, ie, the subject may be trisomic for one of the $\mathrm{G}$ chromosomes.

To visualize the replication behaviour of the involved chromosome with time we prepared Figure 8 . Since the total grain count $(t)$ is known to fall steadily during the last part of the $S$ period, we used an approximate time scale in the reverse direction, the highest counts being earliest in time. Figure 7 was drawn using $t$ as a

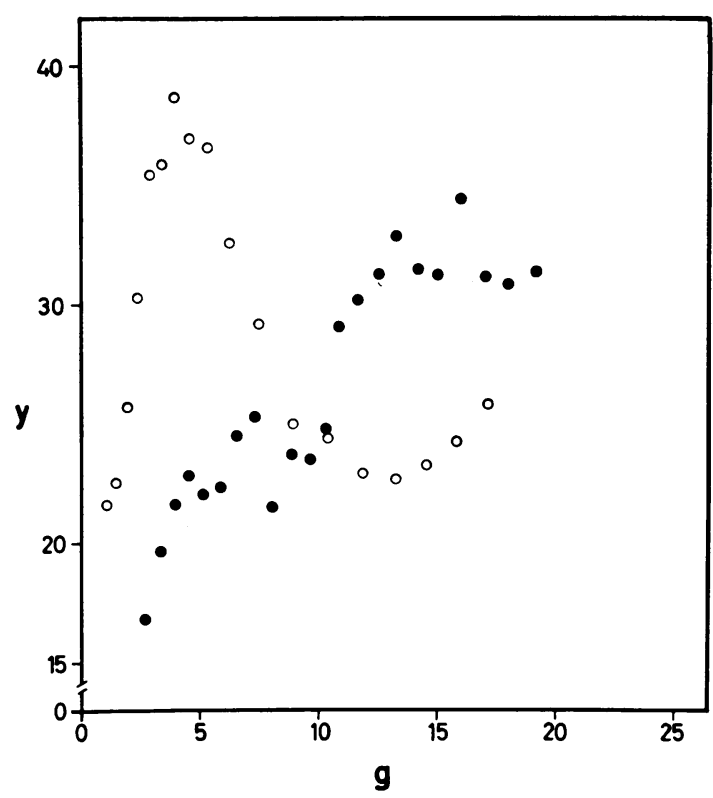

Fig. 6. Analysis of grain counts. Moving averages of $\mathrm{g} 12(0)$ and of $\mathbf{g} 345$ ( $\bigcirc$ ) plotted against the corresponding value of $y$ (see text for details).

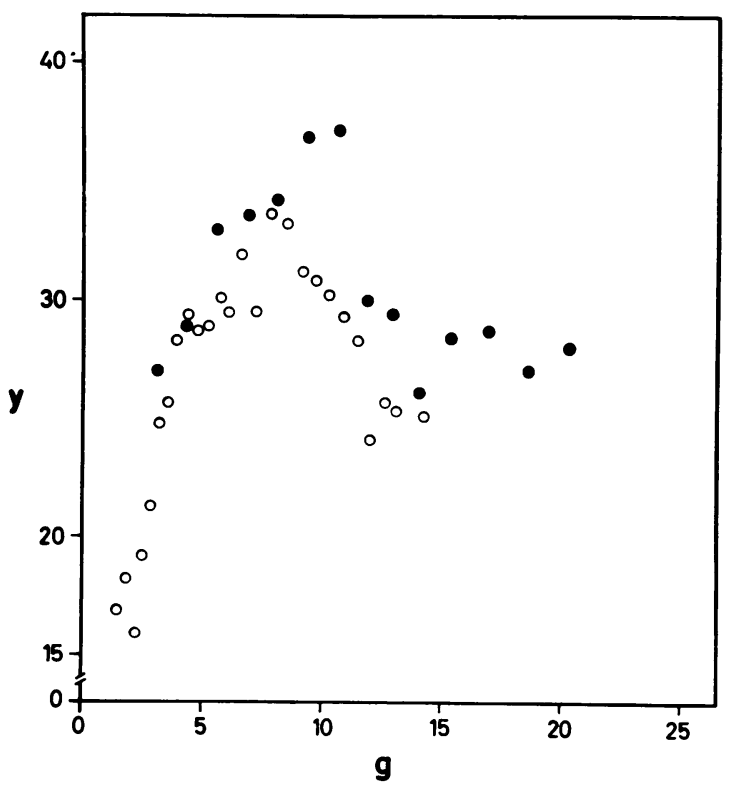

Fig. 7. Moving average of $\mathrm{g} 1$ (O) and of $\mathrm{g} 2345$ ( $\bigcirc)$ plotted against the corresponding values of $y$ (see text for details). 


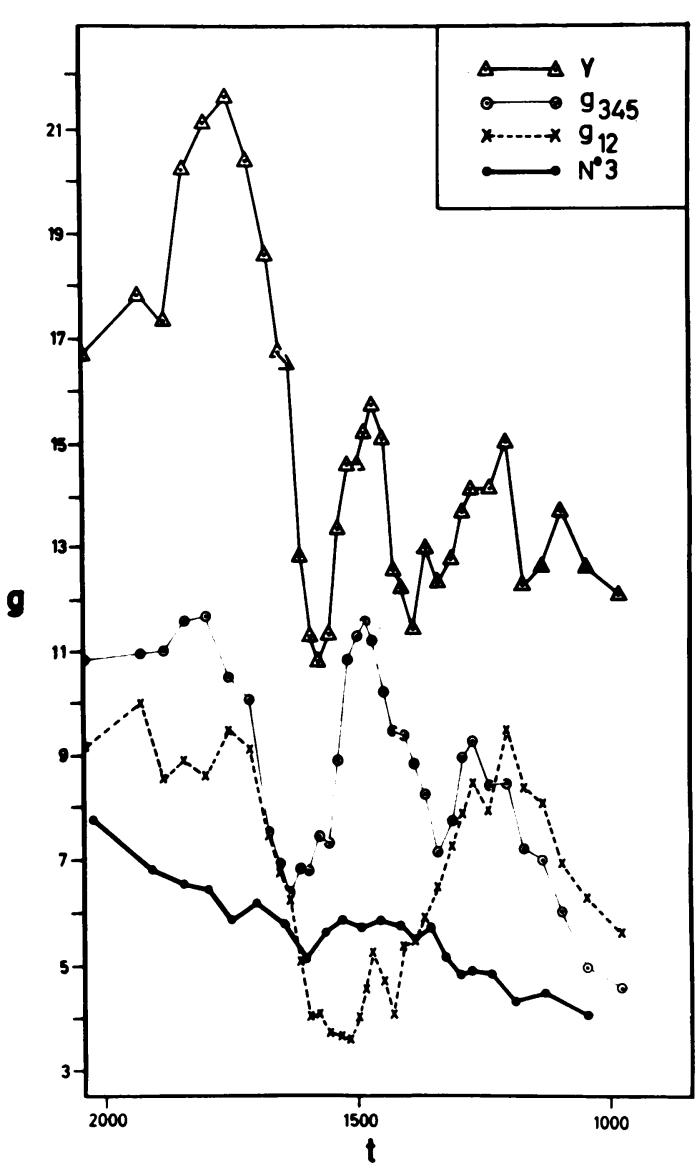

FIG. 8. Moving average of the $Y$ chromosomes, of the grouped $G$

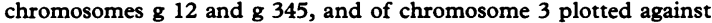
the time scale $t$, based on the total cell grain counts (see text for details).

base and plotting moving average of 7 values as before. In this figure, however, the grain count has been divided by approximate chromosome size as taken from the Denver system. The $\mathrm{Y}$ chromosome and the Gs give multipeaked curves. The counts for chromosomes 1,2 , and 3 from the same cells were plotted on to the same graph and they gave almost steadily decreasing grain counts. The fluctuations shown by the $G$ s and $Y$ chromosomes could be due to the existence of successive, discrete bursts of synthesis along these chromosomes, the $\mathrm{Y}$ being constantly more labelled than the Gs.

\section{Comment}

A severely mentally retarded boy-with no signs of mongolism and with an additional G-like chromosome-is described. Fluorescence analysis excluded an extra Y chromosome while morphologically it was not possible to decide whether the additional chromosome was homologous to those of pair 21-22. Qualitative autoradiography was similarly inconclusive, while quantitative handling of grain counts indicated that the extra chromosome could be homologous in replication to one of the two pairs of G chromosomes. Thus, having excluded mongolism on clinical grounds, this could be a case of trisomy 22. However, our experience with the study of replication patterns of the $\mathrm{G}$ chromosome indicates that these patterns are not characteristic enough to permit a firm conclusion (Fraccaro et al, 1967). The problem of trisomy 22 has been recently discussed by Uchida et al (1968), Moore and Engel (1968), and Nielsen et al (1969), but no firm evidence for its existence has been obtained. The phenotypic variation among the presumptive cases of trisomy 22 and the alternative cytogenetical hypotheses which can be made in most cases, including the present one (see Nielsen et al, 1969 for extensive discussion), leaves the problem unsettled.

\section{Summary}

A severely mentally retarded boy with no signs of mongolism had an additional G-like chromosome. Fluorescence microscopy after staining with atebrin ruled out the presence of an extra $Y$ chromosome. A statistical analysis of autoradiographic grain counts indicated the formal possibility that the extra chromosome was homologous with one of the two pairs of $\mathrm{G}$ chromosomes. These results were not considered sufficient to conclude that this was a case of trisomy 22.

The expenses for the present study were covered by grants from the Swedish Medical Research Council; CNR, Rome; Euratom-University of Pavia Contract no. 023-63-2 BIOI and the USA Atomic Energy Commission. The authors gratefully acknowledge Professor L. S. Penrose for the dermatoglyphic analysis, $\mathrm{Dr}$ A. Heiken for the analysis of the blood groups and serum types, and Dr E. Robson for analysis of the red cell enzymes.

\section{REFERENCES}

Fraccaro, M., Tiepolo, L., Lindsten. J., Hultén, M., Linné, T., and Andrews, D. (1967). DNA replication patterns of chromosomes numbers $21-22$ in female mosaic mongols. In Mongolism, ed. G. E. W. Wolstenholme and R. Porter, pp. 62-69. (Ciba Foundation Study Group No. 25.) London, Churchill.

Moore, M. K. and Engel, E. (1968). G chromosome trisomy: five cases with syndromes other than classical Down's. Southern Medical Fournal, 61, 146-154.

Nielsen, J., Tsuboi, T., Friedrich, U., Mikkelsen, M., Lund, B., and Steinicke, O. (1969). Additional small acrocentric chromosome: two cases. Fournal of Mental Deficiency Research, 13, 106-122.

Pearson, P. L., Bobrow, M., and Vosa, C. G. (1970). Technique for identifying $\mathbf{Y}$ chromosomes in human interphase nuclei. Nature (London), 226, 78-80.

Uchida, I. A., Ray, M., McRae, K. N., and Besant, D. F. (1968) Familial occurrence of trisomy 22. American fournal of Human Genetics, 20, 107-118. 